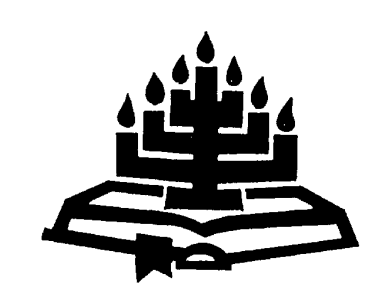

\title{
Zending: waarom? Verbond als antwoord
}

\author{
B. Wielenga \& A. König \\ Fakulteit Teologie en Godsdienswetenskap \\ Universiteit van Suid-Afrika \\ PRETORIA \\ E-pos: wielenga@pmb.lia.net
}

\begin{abstract}
Mission: why? Covenant as answer

In this article we probe the possibilities of a covenantal approach towards Reformed mission theology. Dogmatically the interrelationship between covenant and creation is focused upon from a structure-analytical perspective on covenant. Missiologically a covenantal approach towards mission is developed - an approach in which the missio dei and the missiones ecclesiae are interlinked regarding the forensic foundation of mission. In conclusion the relevance of covenantal cult and law for mission is emphasized.
\end{abstract}

\section{Inleiding}

Sinds ik aan het einde van de zestigerjaren in mijn vaders studeerkamer het proefschrift van D.C.S. van der Merwe (1965) ontdekte, heeft de titel ervan mij geïntrigeerd, ook al bleek mij later dat ik inhoudelijk er niet echt mee uit de voeten kon. Maar ons onderzoek bevestigt dat Van der Merwe terecht aandacht vroeg voor een vergeten thema in de gereformeerde theologie in het algemeen en de gereformeerde missiologie in het bijzonder. De verbondstheologie kon wel eens een waardevol zendingstheologisch paradigma opleveren, waarmee ook in het Afrika van de 21ste eeuw vruchtbaar gewerkt kan worden. Dit artikel dragen we op aan Van der Merwe 's nagedachtenis.

\subsection{Focus van onderzoek}

In ons onderzoek zullen we ons in het bijzonder bezighouden met de vraag naar het waarom van de zending. Waarom zet de christelijke kerk zich eigenlijk in voor zending? Meestal wordt deze vraag in de modernere zendingstheologie overgeslagen, en wordt er onmiddellijk ingegaan op de vraag wat zending eigenlijk inhoudt. We zullen niet graag ontkennen dat deze vraag van centraal belang 
is in welke zendingstheologie dan ook. Wel zijn we van mening dat de watvraag ontspringt aan de waarom-vraag. En juist in een tijd waarin er weinig tolerantie is voor zending binnen en buiten de kerk, en zij hooguit als dialoog (Mulder, 1978; 1980) nog een plaats ontvangt, of eenvoudigweg wordt vergeten (Meijering, 1996), is het noodzakelijk theologisch diep na te denken over de vraag waarom ondanks de aanslagen van buitenaf en de aanvechtingen van binnenuit de kerk aan haar roeping tot zending getrouw blijft.

Scherer (1987:35) merkt op dat pas sinds de vijftigerjaren de zendingstheologie echt van de grond kwam, toen zending namelijk meer en meer tot een probleem werd als vrucht van de crisis waarin de Westerse kerk terecht gekomen was als gevolg van de steeds verder oprukkende secularisatie en de verhorizontalisering van het geloof. Er kwam behoefte aan om opnieuw de fundering en de rechtvaardiging van de zending als geheel eigen taak in het takenpakket van de kerk te doordenken. Inderdaad is zending sinds het einde van de vijfigerjaren meer en meer tot een probleem geworden, vooral ook binnen de kerk. Was Scherer nog vrij optimistisch over de mogelijkheden van kerk en theologie om de crisis van de zending te boven te komen, Shenk (1996:31 e.v.) merkt een tiental jaren later op dat er op zendingstheologisch terrein nog maar weinig bereikt is. Ook het postmoderne zendingsparadigma dat Bosch (1991) probeerde te ontwikkelen, heeft daaraan niets veranderd: "Indeed, his work underscores the absence of conceptual unity at the level of a controlling paradigm" (Shenk, 1996:32). Dit brengt ons ertoe om na te gaan of de gereformeerde verbondstheologie wél in staat is het gevraagde paradigma te leveren waarbinnen een positieve beantwoording van de vraag naar zending - waarom? kan worden gegeven. We concentreren ons in deze bijdrage niet op de theologisch-historische en bijbelstheologische aspecten van de gereformeerde verbondstheologie (zie Wielenga, 1998:23-168), maar op de ook in de gereformeerde zendingstheologie sterk verwaarloosde systematisch theologische verwerking ervan (zie Wielenga, 1998:169-234).

\subsection{Methodologische vooronderstellingen}

We staan in de traditie van de gereformeerde verbondstheologie, zoals die door Schilder is bemiddeld (Schilder, 1954; zie Veldhuizen, 1995), en die critisch staat tegenover de verwerking ervan in de na-reformatorische Gereformeerde Orthodoxie (Graafland, 1992; 1994; Verboom, 1996). De theologische biografie is hermeneutisch van belang.

Een ander hermeneutisch belangrijk punt stippen wij kort even aan. In de dogmatiek komt alleen de geïnterpreteerde Schrift ter sprake. Hoe de Schrift wordt gebruikt in de gereformeerde verbondstheologie is van cruciaal belang. Wij benaderen de Schrift canon-historisch, wat betekent dat de opbouw van de canon van het Oude Testament, zoals we die uit de Westerse (LXX) traditie ontvangen hebben, voor ons gezaghebbend is. Kenmerkend voor de canon als 
geheel is dan niet alleen de kerugmatische eenheid, maar ook het historischeschatologische karakter ervan: de canon heeft niet toevallig dit begin en dit einde met als middelpunt de middelaar Gods en der mensen Jezus Christus. Een van de consequenties van deze visie op de canon is dat we de bijbel alleen gezaghebbend kunnen lezen, als we van Oud naar Nieuwe Testament toe lezen (zie Wielenga, 1998:16 e.v.). Uiteraard moet daarna ook de beweging terug gemaakt worden: van het Nieuwe terug naar het Oude Testament. Berkhof (1966; 1993:81-94) omschreef deze leesmethode met aan Van Ruler (1945:149) ontleende terminologie als volgt: Christus is eerst Lesefrucht van het Oude Testament, en daarna pas Leseprinzip. Voor een bijbelstheologische behandeling van het verbond moet bij het Oude Testament begonnen worden, bij het begin van de canon, Genesis 1, zonder dat nieuwtestamentisch materiaal in eerste instantie ter verklaring van de oudtestamentische data mag worden aangewend; dat kan pas in een later stadium gebeuren. Zo kan ook de historische ontwikkeling serieus in rekening gebracht worden, die het verbond in haar verschillende stadia doorlopen heeft.

Omdat alleen de geïnterpreteerde Schrift in de dogmatiek ter sprake komt, is de dogmatiek nooit af en altijd onderweg. Het moet ons er ook voor bewaren onze interpretaties gelijk te stellen met de Schrift zelf. Onze verbondstheologie, hoe zeer ook genormeerd door de Bijbel en geörienteerd aan de geldende geloofsbelijdenissen, blijft gebaseerd op de geïnterpreteerde Schrift, en kan nimmer het laatste woord hebben.

\section{Het verbond dogmatisch gewogen}

Op grond van ons bijbelstheologisch onderzoek (zie Wielenga, 1998:45-168) kom wij tot de volgende definitie van wat verbond is: het is een asymetrisch samenwerkingsverband tussen God en mensen naar zijn beeld geschapen, dat unilateraal door God scheppend tot stand werd gebracht, en dat door Hem bilateraal wordt onderhouden totdat het volledig is gerealiseerd op een ten volle tot ontplooiing gebrachte aarde, en dat door Hem forensisch is gefundeerd.

\subsection{Verbond en schepping}

Wij zijn van mening dat theologisch het verbond aan de schepping voorafgaat (vgl. König, 1988:147 e.v.). Daarmee geven wij Barth (1932-1967) nog geen gelijk, die het zelfde zei in zijn beroemd geworden formule: (de schepping) "ist die äussere Grund des Bundes, der Bund aber der innere Grund der Schöpfung" (Kirchliche Dogmatik III/1:68, 103, 261). Het probleem bij Barth is dat hij als gevolg van het laten vallen van een historische zondeval genoodzaakt werd verbond en verlossing te laten samenvallen. Bij hem gaat de verzoening in Christus aan de schepping vooraf. We laten de implicaties van zijn visie verder rusten (Wielenga, 1998:170-177). Nu zou onze stelling nog kunnen rusten op het fundament van een pactum salutis-theologie; in Gods eeuwige raad sloot Hij 
een intertrinitarisch verbond met het oog op de verlossing van de uitverkorenen. Deze theologie heeft echter geen houvast in het bijbelse materiaal (Wielenga, 1996:457 e.v.; 1998:41 e.v.; 70 e.v.). Die kant willen wij niet op.

Het verbond ging in dèze zin aan de schepping vooraf, dat God schiep met het oog op het verbond. Het verbond is het doel van de schepping: een volmaakt samenlevingsverband op een volledig ontplooide aarde, die totaal aan het haar ingeschapen potentiaal beantwoordt. De zondeval veroorzaakte wel een nieuwe uitbouw van het verbond; het werd soteriologisch uitgebouwd; maar het verbond veranderde daardoor niet van karakter en bleef als doel der schepping gehandhaafd. Wij menen mede op grond van de betekenis van het Noachitische verbond in de geschiedenis van het genadeverbond te mogen stellen dat de schepping dan ook een verbondsstructuur ontvangen heeft. Bijbelstheologisch kan dat ook nader geadstrueerd worden aan de betekenis van de uitdrukking dat God de werkelijkheid als hemel en aarde schiep (Genesis 1:1). Terecht wijst Houtman (1974:126 e.v.; 145 e.v.) erop dat dit een gefixeerd woordpaar is, dat de gehele geschapen werkelijkheid aanduidt, waarvan de hemel, naar een woord van Moltmann (1986:82), de determinerende en de aarde de gedetermineerde factor uitmaakt. We geven dat als volgt weer: het gaat om de aarde, maar het draait om de hemel in de door God geschapen werkelijkheid; en al draait het om de hemel, het gaat wel degelijk om de aarde. De structuur van het verbond is in de schepping van hemel en aarde al voorgegeven. Met de schepping neemt de geschiedenis van het verbond een aanvang.

We menen dan ook dat het mogelijk is de scheppingsleer in correspondentie met de verbondsleer trinitarisch te ontwikkelen. Verbond en schepping zijn inderdaad binnen- en buitenkant van elkaar, maar dan niet in de zin van Barth.

\subsection{Structuur-analyse van het verbond}

Van onder anderen Schilder hebben we geleerd dat het verbond een monopleurisch ontstaan, een dipleurisch voortbestaan en een forensische fundering kent. We menen dat dit inderdaad bijbelstheologisch uit de Schrift kan worden opgemaakt (vgl. Wielenga, 1998). Kort willen we op deze drie structuurelementen van het verbond ingaan, die ook van belang zijn bij een analyse van schepping en openbaring.

\subsubsection{Het unilaterale ontstaan van het verbond}

Terecht wordt er in de gereformeerde verbondstheologie benadrukt dat het verbond unilateraal door de Drie-ene God tot stand werd gebracht. Er was voor God geen innerlijke noodzaak om een verbond op te richten en daarom tot de schepping te besluiten. Wij kunnen er alleen van zeggen dat God redenen uit zichzelf genomen heeft, die pasten bij zoals Hij is en zoals wij hem mogen kennen uit de Schrift, wat er op neerkomt dat Hij in vrije liefde tot verbond en 
schepping besloot. Verbond en schepping doen ons God kennen, zoals Hij zich te kennen heeft willen geven. Vandaar dan ook dat wij ook de openbaring in onze structuuranalyse van het verbond zullen dienen te betrekken. In het verbond speelt het spreken van God een cruciale rol, zoals dat ook bij de schepping het geval was. Dit veronderstelt openbaring. Wij zouden van verbond en ook van schepping geen weet hebben gehad, als er van openbaring geen sprake zou zijn geweest. Verbond en schepping bemiddelen Gods openbaring, waarvan de Schrift het canonieke getuigenis is. De schepping door het Woord, door Johannes terecht verstaan als de eeuwige Zoon, kan als openbaringsdaad aangemerkt worden. Met deze God openbarende schepping nam het verbond haar aanvang. Wij gaan er wegens ruimtegebrek aan voorbij dat God Drie-enig het verbond scheppend in aanzijn riep. Wij zullen ons af dienen te vragen hoe de Zoon en de Geest bij Gods scheppingswerk betrokken waren (Wielenga, 1998:190 e.v.) als ook in de onderhouding ervan.

Met de schepping nam de verbondsgeschiedenis een aanvang - de geschiedenis waarin de verantwoordelijkheid van mensen ervoor onze aandacht nog zal moeten hebben. Maar verbond impliceert onzes inziens geschiedenis, die door God unilateraal op gang wordt gehouden op weg naar het door hem gestelde scheppingsdoel: de volle ontplooiing van het asymetrische samenlevingsverband tussen Hem en zijn beelddragers en bondgenoten op een volledig aan haar potentiaal beantwoordende aarde. Daarom is er ook coherentie in de verbondsgeschiedenis. Het verbond blijkt onverbrekelijk, omdat God niet op zijn eenmaal genomen besluit terugkomt in zijn onveranderlijke trouw, die zeer wezenlijk voor God is. Dit zouden we niet willen uitleggen in het kader van een causaalpredestinatiaanse uitverkiezingstheorie, zoals soms gebeurt in kringen van de Gereformeerde Orthodoxie, waarin aan de verantwoordelijkheid van de mens tekort gedaan wordt. Maar temidden van alle contingentie van de ene verbondsgeschiedenis blijft God in soevereine liefde vasthouden aan zijn oorspronkelijke plan het verbond op aarde te verwezenlijken. Zondeval en zondvloed brachten geen wijziging in Gods plannen. Zelfs de zonde met het gouden kalf (Exodus 32-34), de grote verbondscrisis in het Oude Testament, of de verwerping van Christus door het Joodse volk, de grote verbondscrisis in het Nieuwe Testament, brachten God niet op andere gedachten.

Dit heeft ook gevolgen voor de schepping. Terwille van het verbond onderhoudt God Drie-enig de schepping, wat in de providentia-leer zou kunnen worden uitgewerkt. De schepping als empirische werkelijkheid is van belang voor het verbond, zoals aan het Noachitische verbond zou kunnen worden geadstrueerd (Wielenga, 1998:64-74; vgl. Wielenga, 1996). De schepping heeft een objectieve capaciteit voor het verbond. De schepping wordt door God in stand gehouden met het oog op het verbond, dat daarom dan ook de binnenkant van de schepping kan worden genoemd, de innere Grund der Schöpfung in Barth's terminologie. De schepping maakt ook deel uit van Gods heilsplan van eeuwig- 
heid. Zoals Christus het normatieve centrum van het verbond is, is hij dat ook van de schepping. De schepping heeft een verbondsstructuur ontvangen, waarvan Christus het normatieve centrum is.

Verbond en schepping veronderstellen openbaring, merkten we al op. We kunnen hier niet ingaan op de onderlinge relatie tussen verbond, schepping en openbaring (Wielenga, 1998:219 e.v.). We benadrukken alleen dat Gods besluit tot stichting van het verbond de schepping door het Woord tot gevolg had, waardoor dan ook de schepping openbaringsgehalte bezit, zoals ook wordt uitgedrukt in artikel 2 van de NGB. Het lijkt ons vanzelfsprekend dat het normatieve centrum van de openbaring Christus is, zoals Hij dat ook is van verbond en schepping. Niet dat er buiten Christus om geen sprake van openbaring zou kunnen zijn. Er is in de gereformeerde theologie altijd gesproken over algemene openbaring in onderscheid van de bijzondere openbaring. $\mathrm{Nu}$ kan op dit onderscheid wel critiek worden uitgeoefend (zo Berkhof, 1993:78) en zelf zouden we ook de voorkeur geven aan een wat flexibeler terminologie (Wielenga, 1998:225). Maar het relatieve nut van het onderscheid blijft toch dat zo erkend wordt dat in Christus Gods openbaring volkomen was, waar de Schrift gezaghebbend getuigenis van aflegt, terwijl hoe verder van Christus als centrum van de verbondsstructuur van de schepping verwijderd, des te zwakker zal de openbaringskracht zijn die aangetroffen wordt in culturen en religies of ook in de abiotische natuur. God openbaart zich in de in de schepping gelegde verbondsstructuur, maar hoe dichter naar het centrum daarvan toe, des te helderder zal zijn openbaring gezien en gekend kunnen worden - en ten volle in zijn Zoon, in wie Hij zich ten volle heeft uitgesproken tot heil van de mens en tot heling van de schepping, wat door de Geest wordt bemiddeld en waar de Schrift canoniek getuigenis van af legt. Een heilsrelatie tot God gaat niet om buiten de Zoon en de Geest; maar dat betekent nog niet dat er daarom verder buiten dit centrum om geen sprake is van openbaring en verbond, wat niet soteriologisch maar wel christologisch bepaald is. Een centrum heeft een periferie; men kan daartussen in zich bevinden of op weg naar of juist weg van het centrum. De richting is bepalend. Maar beide openbaringsmodi hebben een gemeenschappelijk centrum in Jezus Christus, waardoor we het onderscheid tussen algemene en bijzondere openbaring relativeren.

\subsubsection{Het bilaterale voortbestaan van het verbond}

Verbond veronderstelt relatie, wederkerigheid. Op grond van ons bijbelstheologische onderzoek (vgl. Wielenga, 1998:45-168) menen we dat het verbond ten alle tijde deze wederkerige relatie impliceert, hoe asymetrisch ze structureel ook mag zijn. De term conditionaliteit is in de gereformeerde verbondstheologie verdacht (zie Schilder, 1996); vandaar dat we opteren voor de term verantwoordelijkheid. God rekent op de menselijke verantwoordelijkheid bij de realisering van zijn plannen. God verwachtte van mensen dat ze in antwoord op zijn belovend spreken positief zouden reageren en gaan partici- 
peren in zijn plan tot realisering van zijn scheppingsdoel. Dat mensen saboteurs in plaats van co-operateurs in de samenwerking werden, doet niets af aan Gods oorspronkelijke bestemmingsplan voor de mens. Van hoeveel belang voor God deze menselijke participatie is, kan blijken uit zijn heilshandelen in Christus tot heil van de mens en tot heling van de schepping. Het spreekt vanzelf dat deze bilateraliteit van het verbond een pneumatologische categorie is; er kan hier geen sprake zijn van synergisme. Om de bilateraliteit te ontkennen uit vrees voor Arminianisme, doet tekort aan het bijbels getuigenis, zoals ook in de Dordtse Leerregels (I,3; III/IV,3) tot uitdrukking wordt gebracht.

Er kan ook alleen maar van verbondsgeschiedenis sprake zijn, als mensen er in verantwoordelijkheid in participeren in gehoorzaamheid aan Gods wet en in gemeenschap met Hem in de cultus. God maakt niet alleen geschiedenis, zouden we ietwat provocerend willen formuleren. Het verbond doorloopt een geschiedenis, die gefaseerd kan worden, waarbij gelet moet worden op continuiteit en discontinuiteit, op contingentie en coherentie. Een en ander houdt in dat verbondsvormen en -gestalten in de ene fase van de verbondsgeschiedenis nog niet in een volgende fase normatief hoeven te zijn. Duidelijk hoort de politieke theocratie thuis in de Mozaïsche fase van de verbondsgeschiedenis, die in de huidige fase geen normatief gezag meer heeft. Dit leert ons dat God in elke fase van de geschiedenis zijn verbond gestalte kan geven; er is geen historische situatie denkbaar waarin het verbond niet vorm en gestalte kan krijgen, waarin mensen niet Gods medewerkers zouden kunnen zijn in de vervulling van zijn scheppingsdoel. Tegelijk moet benadrukt worden dat het verbondsvervormend potentiaal in elke historische situatie als gevolg van de anti-machten en tegenkrachten der duisternis, even serieus genomen moet worden. Van belang is in het heden te beantwoorden aan het normatieve verbondscentrum Christus, in wie God in principe het verbond heeft verwerkelijkt. Wat tegen Hem ingaat, zoals canoniek betuigd in de Schrift, moet afgewezen worden. Zo kan ook aan de coherentie in de verbondsgeschiedenis recht gedaan worden.

Dit accent op de bilateraliteit van het verbond heeft ook gevolgen voor onze visie op de schepping en de openbaring, die het verbond veronderstellen en daardoor ook worden gestructureerd. Wordt, bij voorbeeld, de schepping in de providentia-leer unilateraal beschouwd, bilateraal moet accent gelegd worden op de menselijke verantwoordelijkheid voor de schepping. Gods bondgenoten zijn sluit in dat de aarde verantwoord wordt ontsloten en ontplooid, beheerd en bewaard. De ecologie komt in de dogmatiek ter sprake. Ook hier moet trouwens gewezen worden op het pneumatologische karakter van het bilaterale verbondsperspectief op de schepping. De Reformatoren noemden juist in dit verband de Geest Creator Spiritus, uitgegaan van de Vader en de Zoon om mensen in staat te stellen de aarde te bewerken en te bewaren met het oog op Gods scheppingsdoel. 
Wat de openbaring aangaat, willen we benadrukken dat openbaring bedoelt een positieve respons op te roepen. Ook hier zijn uni- en bilateraliteit op elkaar betrokken; er is sprake van een asymetrische wederkerigheid. Ook als die respons negatief is tegen de bedoeling van God in - want waarom zou God zich anders openbaren behalve om een positieve respons te ontvangen? - heeft er toch openbaring plaats gevonden, waarmee we tegen Berkhof (1993:78 e.v.) kiezen, voor wie openbaring ontmoeting inhoudt; zonder respons vindt er volgens hem geen ontmoeting plaats. Maar openbaring is dan ook niet hetzelfde als ontmoeting. Ook een negatieve respons impliceert dat er openbaring is geweest; anders krijgen wij onoverkomelijke problemen in de theologia religionum, waarin voor de schuld der heidenen dan geen plaats meer over is. Het gaat in Gods openbaring om verbond, waardoor men Hem leert kennen zò, zoals Hij is. God openbaart zich in de schepping - de empirische werkelijkheid met natuur, cultuur en religie - die door de erin gelegde verbondsstructuur wordt bepaald; en door ziijn woorden en daden van heil in de geschiedenis van zijn volk, waarvan we het canonieke getuigenis bezitten in de Schrift, die dan ook openbaringsgehalte bezit. Hier liggen natuurlijk erg veel moeilijke vragen, waarmee al vanaf het begin van de kerkgeschiedenis geworsteld is (zie Meijering, 1995). Maar de openbaring vanuit het verbondsperspectief belichten, impliceert dat Gods openbaring een positieve respons bedoelt op te roepen, geloof en gehoorzaamheid, participatie en co-operatie met God. Als dat toch niet gebeurt, vindt het onmogelijke plaats, zoals ook de zondeval niet mogelijk had behoren te zijn.

\subsubsection{De forensische fundering van het verbond}

Verbond kan een verbintenis genoemd worden met een juridisch aandoende structuur. In een publiek ritueel wordt een al bestaande relatie geformaliseerd in een verbondsstatuut waarin beloften, eisen en sancties zijn vastgelegd. Deze forensische structuur dient ter bevestiging, bescherming en stabilisering van waar het in het verbond omgaat: de omgang en samenwerking tussen God en mensen met het oog op de realisatie van het scheppingsdoel. Het is dan ook een postlapsarische heilscategorie, waarmee de zekerheid van de mens wordt gediend. Dit heeft gevolgen voor de schepping, wier binnenkant het verbond is. We zagen al dat de schepping een objectieve capaciteit voor het verbond heeft en het zo ook kan faciliteren. Maar zo wordt het behoud en de toekomst van de schepping ook verzekerd terwille van het verbond. De forensische structuur van het verbond garandeert het voortbestaan van de schepping, zelfs door het eindoordeel heen. De realisering van het verbond betekent niet het einde van de schepping maar haar verheerlijking (Rom. 8:18 e.v.).

Het verbond, dat sinds de zondeval genadeverbond is, omvat maar niet de van eeuwigheid uitverkorenen - een anthropocentrische reductie van de verbondswerkelijkheid - maar de gehele geschapen werkelijkheid. Er is een verbintenis tussen de Schepper en de geschapen werkelijkheid, waarvan Jezus Christus het 
normatieve centrum uitmaakt. Niets en niemand valt dan ook buiten deze door het verbond gestructureerde werkelijkheid. Dit betekent echter niet dat alles en allen binnen deze werkelijkheid in een heilsrelatie tot God staan. Heil en heling komen op vanuit het centrum Jezus Christus; men kan dichterbij of verderaf van dat centrum zich bevinden afhankelijk ook van de richting waarin men zich beweegt: naar het centrum toe of er juist vanaf (Wielenga, 1998:208). Er valt een centrum en een periferie aan de verbondswerkelijkheid te onderscheiden. De heilsrelatie loopt via het centrum. Wel kan zo beargumenteerd worden dat er buiten het centrum om verbondsanaloge momenten te onderkennen zijn in de wereld der volkeren, in hun culturen en religies, zodat niet ontkend hoeft te worden dat er veel goeds te waarderen valt in de wereld. Niets gaat om buiten de verbondswerkelijkheid, waarvan Christus het centrum is; ook de periferie is op dat centrum betrokken. Maar zaligmakend heil valt slechts hen ten deel die in Christus zijn, met het centrum door geloof in genade verbonden. De schepping als de buitenkant van het verbond kan rekenen op heling, wanneer de kinderen Gods openbaar zullen worden (Rom. 8:18 e.v.). We moeten hier verder aan voorbijgaan.

Wat betekent deze forensische visie op verbond en schepping nu voor de openbaring? Een enkele opmerking daarover ter afsluiting van deze paragraaf. We zouden het forensische aspect van de openbaring vooral willen aanwijzen in de Schrift als het canonieke openbaringsgetuigenis. Gods openbaring kent twee modi: door middel van de schepping en door middel van zijn heilshandelen binnen de schepping. We hebben daar echter absoluut zeker weet van vanuit de Schrift, als canoniek, dat is gezaghebbend en normatief getuigenis van beide modi der openbaring. Zonder de Schrift is het onmogelijk de werkelijkheid als door het verbond gestructureerde werkelijkheid te doorgronden of kennis te hebben van Gods heilshandelen in Israel en in Christus. We moeten de Schriftleer hier verder laten rusten. We zouden dan nader moeten ingaan op de creatuurlijkheid van de openbaring en de gevolgen daarvan voor de Schrift als openbaringsgetuigenis.

\section{Verbond en zending}

Welke missiologische conclusies trekken we nu uit deze dogmatische overwegingen? Vatten we nog eens kort samen waar het in deze overwegingen omgaat. Het verbond gaat theologisch aan de schepping vooraf, mits het niet soteriologisch wordt gereduceerd. Verbond en schepping worden als binnen- en buitenkant aan elkaar gerelateerd met gevolgen voor de openbaring, die met het verbond als inhoud verbondsmatig gestructureerd is. Centrum en integratiepunt van verbond, schepping en openbaring is Jezus Christus, de eeuwige Zoon van God die vlees geworden is. Ook al benadrukken we dat de gehele geschapen werkelijkheid verbondsmatig gestructureerd is met Christus als centrum en integratiepunt, waardoor zij openbaringsgehalte bezit die naar het centrum toe zich steeds meer verdicht en naar de periferie toe zich steeds meer verdunt, 
niettemin gewordt het heil van de mens en de heling van de schepping alleen in en door het centrum, in Christus.

Er is alle reden voor om te veronderstellen dat van meet af aan in Gods Raad verbond en zending aan elkaar gerelateerd zijn geweest als binnen- en buitenkant. Gods besluit tot verbond bracht vanuit de mens gezien een beweging op gang die tot schepping leidde, waarmee de verbondsgeschiedenis een aanvang nam. Dit impliceert dat God van meet af aan op de mens als bondgenoot heeft gerekend bij de uitvoering van zijn scheppingsdoel. Verbond is nu eenmaal bilateraal in haar voortbestaan.

De weg waarlangs God zijn doel in samenwerking met mensen op aarde wilde bereiken, zouden wij zending willen noemen. Zending is de beweging door God op gang gebracht al van vóór de schepping om een voltooid samenlevingsverband met mensen op een ontsloten en voltooide aarde te realiseren (Wielenga, 1998:239 e.v.).

"Zending is doelgerichte beweging, verbondsmatig gestructureerd" (Wielenga, 1998:240). Zending is in de Godsleer gefundeerd; de wil van God, die overigens met zijn wezen overeenstemt (Meijering, 1996:74 e.v.; 87 e.v.), staat garant voor het welslagen van de zending. Juist omdat God een zendende God is, is er sprake van openbaring. Missio resulteert in revelatio. Wij bespreken verder de onderlinge relatie tussen verbond en zending,

\subsection{Missio dei als unilateraal verbondsperspectief op zending}

Sinds Hartenstein in 1933 Barth's conceptie van de missio dei in de zendingstheologie aanwendde om de verhorizontalisering van de zending tegen te gaan, heeft het over een breed spectrum van kerk en theologie ingang gevonden (Vicedom, 1965). Leverde het aanvankelijk een sterk ecclesiocentrisch georienteerde zendingstheorie op, waarin de Drie-ene God centraal stond die door zijn kerk op aarde zijn zending voltooide, het werd onder invloed van J.C. Hoekendijk een steeds sterker theocentrisch gestructureerde theorie, volgens welke God zelf rechtsstreeks in de geschiedenis aan het werk is, ook wel zonder kerk en evangelieverkondiging, daarbij ook onderbouwd door een kosmische christologie of tegenwoordig ook wel pneumatologie (Bosch, 1991: 389 e.v.; Aagaard, 1973:8 e.v.; Graafland, 1978:71 e.v.). Heil werd destijds ook sterk horizontalistisch, binnenwereldlijk gedefinieerd; het was vaak niet meer dan welzijn voor de mens en heling van de schepping; maar daar komt men meer en meer van terug (Scherer, 1987:145 e.v.). Heil wordt veelal holistisch verstaan, zowel in oecumenische als evangelische zendingskringen (Bosch, 1989; Breman, 1996). We stemmen daarmee in, mits onthouden wordt dat theologisch heil primair te maken heeft met het behouden worden van de komende toorn van God, een vergeten thema in de modernere missiologie. Towner (1995:99 e.v.) verwijst speciaal naar het zendingsparadigma van 
Johannes, bij wie het oordeel van God over een zondige wereld duidelijk gedocumenteerd is. Dat hier het al dan niet verrekenen van de zondeval in de theologie een doorslaggevende rol speelt, lijkt ons onweerlegbaar. In de zendingstheologie zal aandacht moeten komen voor zonde als verbondsbreuk, die juist in de verwerping van Christus haar diepste crisis bereikt, waarbij toorn van God als verbondssanctie past. Uiteraard, heil is integraal en holistisch, maar het kent te onderscheiden aspecten, die wel aan een theologische rangorde maar lang niet altijd aan een chronologische volgorde onderworpen zijn.

Maar een verbondsmatige verwerking van de missio dei-conceptie kan het afschermen tegen horizontalistische afvlakking ervan zonder dat het verticalistisch irrelevant wordt voor déze wereld in déze geschiedenis. In zending, verbondsmatig gestructureerd, gaat het inderdaad centraal om de Drie-ene God die soeverein en genadig zijn scheppingsdoel realiseert in de geschiedenis op deze aarde; maar hij wil dat niet anders doen dan in samenwerking met zijn bondgenoten en beelddragers, die zijn volk op aarde vormen. Unilateraal en bilateraal zijn ook in de zending correlatief op elkaar betrokken. Ook iemand als Gensichen (1971:56 e.v.) benadrukt dit, wanneer hij stelt dat de missio dei de missiones ecclesiae fundeert, waarbij de eerste in de laatsten aan het licht komt. De verbondsmatige structuur van de missio dei bepaalt Gods werkwijze: God spreekt! Sprekend schiep Hij, sprekend leidt Hij de geschiedenis tot het haar door Hem gestelde doel, sprekend voltrekt Hij zo zijn schepping en geschiedenis omvattende zending. Maar waar sprake is van het spreken Gods, spreken we van revelatio, waar mensen van getuigen kunnen, en komt ook de inspiratio verbi dei in het zicht. Terecht zegt dan ook Vicedom (1965:45) dat er revelatio is, omdat er missio dei is, waar wij aan toevoegen dat er inspiratio is, omdat er missio is.

Kortom, zending is beweging, die opkomt uit Gods wezen naar zijn wil, en vanaf de schepping een geschiedenis doorloopt. Zending is dan ook opus proprium dei en heeft geen opus proprium - een discussie waar we nu verder aan voorbij gaan. God gebruikt heel de schepping en haar geschiedenis om zijn gestelde doel, het voltooide verbond, te bereiken. Alles en allen werken daar bewust of niet aan mee, soeverein als God alles en allen voor dat ene doel inzet. We kunnen zelfs stellen dat sinds de verwerping van Christus door Israel de zendingsgeschiedenis in haar apocalyptische fase is gekomen. De grootste verbondscrisis aller tijden bracht een nieuw verbondsherstellend initiatief van Gods kant te weeg: het daadwerkelijk uittrekken naar de volkeren in wat dan centrifugale zending wordt genoemd, een geheel nieuw fenomeen op het veld van de religies. De volkerenpelgrimage naar Zion uit de profetische vergezichten leek stuk te lopen op Israels onwil haar Messias te aanvaarden, in wie het verbond vervuld werd. Maar op de Pinksterdag werd Gods antwoord al zichtbaar: de uitstorting van de Geest en de bekwaammaking van de getuigen, die door de Geest de weg naar de volkeren werden opgedrongen. Zending als het 
uittrekken naar de volkeren als getuigen van Gods openbaring is teken en zegel van het apocalyptische karakter van het huidige tijdsgewricht. De urgentie is in de geschiedenis gekomen, omdat het einde thans imminent is: de Heer is nabij!

\subsection{Missiones ecclesiae als bilateraal verbondsperspectief op de zending}

Waar zending verbondsmatig wordt benaderd, is een bilaterale participatie in de missio dei door de mens een sine qua non. Krachtens en op de wijze van het verbond voltooit God zijn scheppingsdoel. Waar sprake van het verbond is, wordt het volk van het verbond een werkelijkheid, door God geconstitueerd en geroepen tot die participatie, wat in de literatuur dan de missiones ecclesiae wordt genoemd. Het verbondsvolk is geen amorfe massa individuele gelovigen die op basis van vrijwillige keuze zich verenigt tot een religieus genootschap, kerk geheten, dat dan de zendingsroeping als opdracht aanvaardt en uitvoert. Het verbondsvolk heeft de ambtelijk georganiseerde kerk als richting gevend structuurcentrum, zodat het verbondsvolk vorm kan geven aan haar participatie in de missio dei. Deze participatie berust niet op een vrije keuze van gelovige individuen, maar behoort tot het wezen van het verbondsvolk, waarzonder ze ophoudt volk van Gods verbond te zijn. De ambtelijk georganiseerde kerk is het verbondsvolk in geconcentreerde vorm; rondom deze kern waaiert het volk uit over de gehele breedte van het leven en is ze missionair werkzaam op alle terreinen daarvan.

We menen te moeten onderscheiden tussen de participatie van de georganiseerde kerk in de missio dei, wat we als missiones ecclesiae zou willen benoemen, en die van het verbondsvolk in ruimere zin, wat we vocationes zouden willen noemen. De vocationes zijn dimensioneler bij de missio dei betrokken dan de missiones, die weer intentioneler daarbij betrokken zijn dan de vocationes. De ambtelijk georganiseerde kerk heeft een beperkter, zij het fundamenteler, zendingsdoel dan het verbondsvolk als totaliteit. De kerk geeft door prediking en onderricht structuur en richting aan de vervulling van de vocationes op alle terreinen van het leven, daarbij ook ondersteund door een christelijke, bijbels geïnspireerde levens- en wereldbeschouwing; zelf leunen we daarvoor aan tegen de Reformatorische Wijsbegeerte (Van Woudenberg, 1992; 1996; Geertsema, 1995). We beperken ons verder tot de missiones ecclesiae. In een gereformeerde zendingstheorie kan slechts de kerk de eigenlijke missionary agency zijn, en niet een zendingsgenootschap (zie Bosch, 1991:327 e.v.). We merken in dit verband het volgende over de kerk op.

We wezen er al op dat het verbond ook de werkwijze van God bepaalt in zijn missio. God spreekt. Er is revelatio waar de kerk van getuigt in woord en daad. Door haar getuigenis zoekt de kerk de wereld te herorienteren op haar heilbrengende en levenschenkende verbondscentrum Jezus Christus. Deze directe en intentionele bemoeienis van de kerk met de wereld wordt gevoed door haar 
voorbede voor de wereld en begeleid door haar diaconale hulpverlening aan de wereld (Hoek, 1996:423), waarbij we instemmen met De Ruijter (1992:155 e.v.) dat het getuigenis niet alleen een kerugmatische maar ook een diaconale gestalte heeft, die beiden op eigen wijze heil bemiddelen. Vandaar dat zending terecht holistisch wordt verstaan, waarbij de verbale gestalte wel een theologische, maar lang niet altijd een chronologische prioriteit heeft boven de diaconale gestalte van zending. De concrete situatie is hier doorslaggevend.

Deze verbondsmatige aanpak van de zending der kerk kan ook voorkomen dat de kerk een functie van het apostolaat wordt, als bij J.C. Hoekendijk het geval was. De kerk is wel opgenomen in Gods beweging naar het gestelde doel; zij is geroepen eraan deel te nemen, haar ook te faciliteren. Maar de kerk is niet alleen in beweging, ze kent ook al rust. Er is eredienst, waar zij het reeds ontvangen heil al mag vieren onder het Woord en rond de Tafel, en waar zij ook al op de beloofde toekomst vierend anticipeert. Juist in de cultus wordt de gemeenschap der heiligen ervaren, de convivençia (zie Sundermeier, 1995); met name daar, zij het niet daar alleen, is kerk ecclesia audiens, behalve adorans, waar ze wordt toegerust tot missio en vocatio in de wereld, haar ten goede. Er is een nauwe samenhang tussen eredienst en zending. Hier zien we het belang om het verbond als binnenkant van de zending te zien. God maakt al passen op de plaats, waardoor de zendingsbeweging op koers blijft en in beweging. Juist in de eredienst haalt de kerk adem om op krachten te komen, zodat zij God in zijn gang door de geschiedenis bij kan houden. Alle elementen van de eredienst hebben trouwens een missionair potentiaal (Wielenga, 1990:304 e.v.).

\subsection{Het sacrament als forensisch verbondsperspectief op de zending}

Het verbond is een in een publiek ceremonieel vastgelegde verbintenis tussen God en mensen, waardoor de al bestaande relatie tussen hen wordt geformaliseerd. Zending als missio ecclesiae beoogt herorientering van mens en wereld op het verbondscentrum van de werkelijkheid Jezus Christus, merkten we al op. We willen dat nu nog scherper formuleren. Zending als missio ecclesiae beoogt met name inlijving van mensen in het verbond en zo verbondenheid met Christus, wat door het doopceremonieel publiek plaatsvindt. De doop is bij uitstek een forensisch structuurelement van de zending der kerk. Door de doop wordt men in het verbondsvolk ingelijfd en gaat men publiek en officieel deel uitmaken van de gemeente als lichaam van Christus. Maar doop verwijst zo, behalve naar het verbondsvolk, ook naar een concrete kerk met haar ambtelijke structuur. Zo wordt de permanentie van zending als missio dei en ecclesiae gegarandeerd. De kerk als doophuis garandeert de voortgang van de zending. Zolang er kerk is, waar gedoopt wordt, behalve dat het Woord er bediend wordt en het Avondmaal gevierd, zal er zending zijn. Er moet kerk zijn, wil er zending kunnen zijn. En er zal kerk zijn, totdat het verbond volledig is gerealiseerd en Gods scheppingsdoel 
is bereikt. We wezen er al op dat juist in de eredienst de kerk haar verbondenheid met God en onderling viert. Er wordt al iets ervaren van de verbondswerkelijkheid, die God door middel van de zending wil verwezenlijken. Er heerst al iets van de beloofde en nog uitstaande sabbatsrust. Daarom is er ook kerk - ambtelijk gestructureerd volgens een geldende kerkenordening, die dan ook missionair relevant dient te zijn.

\subsection{Zending als buitenkant van het verbond}

We komen aan het einde van dit structuuranalytische onderzoek naar de relatie tussen zending en verbond. Eerst stellen we de betekenis van de zending als buitenkant van het verbond nog aan de orde. De zending is de buitenkant van het verbond. Zo wordt de veelal exclusieve en statische verbondsbeschouwing van de Gereformeerde Orthodoxie inclusief en dynamisch omgebouwd. Door de zending als buitenkant van het verbond te beschouwen wordt het eschatologisch op de voltooiing ervan gericht en ontvangt het een de werkelijkheid omspannende reikwijdte. Verbond is dus bepaald geen binnenkerkelijk gebeuren, waarin de verticale dimensie centraal staat - de heilsrelatie tussen God en zijn uitverkoren kinderen. Dit kan tot heilsindividualisme leiden, die vreemd is aan de Schrift. Het persoonlijk beleefde heil geschiedt altijd binnen de kaders van het verbond en dus in gemeenschap met het verbondsvolk en in betrekking tot de ganse schepping. Voor alle duidelijkheid voegen we eraan toe dat we hiermee niet de uitverkiezing theologisch tussen haakjes willen plaatsen; theologisch kan de uitverkiezing het best doordacht worden als het unilaterale structuurelement van het verbond; de uitverkiezing is echter vooral zaak van het doxologisch belijden van de kerk als geloofsgemeenschap in overeenstemming met de hymnologische context waarin de uitverkiezing in het Nieuwe Testament meestal ter sprake komt (Ef. 1; Rom. 11).

\subsection{Verbond als binnenkant van de zending}

Het cultische perspectief op de zending, waar we al even op ingingen bij de bespreking van de relatie tussen zending en eredienst, is cruciaal voor een gereformeerde zendingstheorie. We gaan er verder aan voorbij om een andere zaak te kunnen bespreken.

Die andere zaak is de wet (zie Wright, 1997). De wet van het verbond raakt het hele aardse leven in al haar facetten, en vraagt erom onderhouden te worden. Dit impliceert niet alleen dat zending zich behoort bezig te houden met alle facetten van het aardse leven, en daarom alleen holistisch verstaan kan worden. Het betekent ook dat de wet alleen gedaan kan worden in onlosmakelijke samenhang met de cultus, waar Christus als vervuller der wet beleden en zijn Geest geschonken wordt. De wet in al haar aspecten (Wright, 1997:152 e.v.) zal in de missiones ecclesiae onderwezen moeten worden, wat zendingsprediking een confrontatieve spits zal geven, aangezien juist in de zending de kerk te maken 
krijgt met andere religies met hun eigen rechtssystemen en waardenstelsels, die diep verankerd zijn in de respectieve culturen. We gaan in dit artikel voorbij aan de theologia religionum; maar juist de prediking van de wet als integraal onderdeel van het missionaire getuigenis van de kerk kan niet anders dan een critisch aangrijpen betekenen van de culturen en de daar geldende religies, zoals de wet deze functie ook behoort te hebben binnen de Westerse cultuur en de daar dominante christelijke religie. Het doen der wet is goed voor mens en wereld, en is missionair van de grootste betekenis. De vormgeving der wet in de concrete historische situaties is vrucht van het werk van de Geest en sluit eenvormigheid uit. De kerk in haar zending exporteert niet de Westerse vormgeving van Gods wet, maar zal alles in het werk stellen om de bijbelse principes achter de wet te expliciteren, zodat in elke cultuur Gods wet vorm en gestalte krijgt door de locale kerk bemiddeld, zodat zij daar als een zoutend zout gaat werken. Zending bedoelt zegenrijk te werken in elke cultuur. Dat dat niet het geval is, betekent niet het bankroet van de zending, maar het dwingt haar er toe in afhankelijkheid van de Heer der zending zonder culturele arrogantie en religieuze hoogmoed zich dienstbaar te blijven stellen aan de missio dei, die door God ondanks christelijk falen toch zal worden verwezenlijkt. Een verbondsmatige benadering van zending zal juist in de plaats die de wet van het verbond daarin ontvangt, op haar gereformeerde gehalte kunnen worden beoordeeld.

\section{Als slot}

Doordenking van de verhouding tussen verbond en zending kan onzes inziens tot de formulering van een paradigma leiden, waarbinnen de gereformeerde zendingstheologie en -practijk zich ten volle kan ontplooien. Binnen dit paradigma worden vanuit het verbond als organiserend principe schepping, openbaring en zending op elkaar betrokken gezien. Zo ontstaat er een verwijzingsraamwerk, waarbinnen de vragen en problemen kunnen worden aangesproken, waar de moderne zending kerk en theologie voor stelt. We bepleiten derhalve een missionair functionele verbondsleer.

\section{Literatuurverwijzingen}

AAGAARD, J. 1973. Trends in missiological thinking during the sixties. International Review of Mission, 52(245):8-25.

BARTH, K. 1932-1967. Die Kirchliche Dogmatik. I/1-IV/4. München-Zollikon-Zürich : EVZ Verlag.

BERKHOF, H. 1966. Om het verbond. Bijlage Maandblad Kerk en Israel, 20(10).

BERKHOF, H. 1993. Christelijk geloof. (7e druk.) Nijkerk : Callenbach.

BOSCH, D.J. 1989. Salvation: A missiological perspective. Ex Auditu, 5:139-158.

BOSCH, D.J. 1991. Transforming mission. Paradigm shifts in theology of mission. Maryknoll : Orbis Books.

BREMAN, C.M. 1996. The Association of Evangelicals in Africa. Its history, organisation, members, projects, external relations and message. Zoetermeer : Boekencentrum. 
DE RUIJTER, C.J. 1992. De horizon van het heil. Theorie en praxis bij Johann Baptist Metz en Clodovis Boff, mede in verband met de verkondiging en het diakonaat van de kerk. Kampen : Kok.

GEERTSEMA, H.G. 1995. Om de humaniteit. Christelijk geloof in gesprek met de moderne cultuur over wetenschap en filosofie. Kampen : Kok.

GENSICHEN, H.W. 1971. Glaube für die Welt. Theologische Aspekte der Mission. Gütersloh : Gütersloher Verlagshaus Gerd Mohn.

GRAAFLAND, C. 1978. Theologische hoofdlijnen. (In Versteeg, J.P. e.a. red. Gij die eertijds verre waart $\Psi$ Een inleiding tot de gereformeerde zendingswetenschap. Utrecht : De Banier. p. 61-138.)

GRAAFLAND, C. 1992. Van Calvijn tot Comrie. Oorsprong en ontwikkeling van de leer van het verbond in het Gereformeerde Protestantisme. I\&II. Zoetermeer : Boekencentrum.

GRAAFLAND, C. 1994. Van Calvijn tot Comrie. Oorsprong en ontwikkeling van de leer van het verbond in het Gereformeerde Protestantisme. III\&IV. Zoetermeer : Boekencentrum.

HOEK, J. 1996. Geheim en gestalte van de gemeente - over de kerk. (In Van den Brink, G. red. Gegrond geloof. Kernpunten uit de geloofsleer. In bijbels, historisch en belijdend perpectief. Zoetermeer : Boekencentrum. p. 401-434.)

HOUTMAN, C. 1974. De hemel in het Oude Testament. Een onderzoek naar de voorstellingen van het Oude Israel omtrent de kosmos. Franeker : Wever.

KÖNIG, A. 1988. New and greater things. Re-evaluating the biblical message of creation. Pretoria : University of South Africa.

MEIJERING, E.P. 1995. Klassieke gestalten van christelijk geloven en denken. Van Irenaeus tot Barth. Amsterdam : Gieben.

MEIJERING, E.P. 1996. Inspiratie uit de traditie. Gegrond geloof. Kampen : Kok.

MOLTMANN, J.M. 1986. God in creation. An ecological doctrine of creation. London : SCM.

MULDER, D.C. 1978. Dialoog als zending. (In Baarda, T.J. e.a. red. Zending op weg naar de toekomst. Essays aangeboden aan Prof. Dr. Joh. Verkuyl. Kampen : Kok. p. 137-145.)

MULDER, D.C. 1980. Van elenctiek naar godsdienstwetenschap. (In Augustijn, C. e.a. red. In rapport met de tijd. 100 jaar theologie aan de Vrije Universiteit. Kampen : Kok. p. 182-197.)

SCHERER, J.A. 1987. Gospel, church and kingdom. Comparative studies in world mission theology. Mineapolis : Augsburg Publishing House.

SCHILDER, K. 1954. Wat is de hemel. Kampen : Kok.

SCHILDER, K. 1996. Extra-Scriptural binding - a new danger. Neerlandia (Can.) : Inheritance publications.

SHENK, W.R. 1996. The role of theory in mission. Missiology, 24:31-45.

SUNDERMEIER, T. 1995. Konvivenz und Differenz. Studien zu einer verstehenden Missionswissenschaft. Erlangen :Verlag der Evangelisch-Lutherische Mission.

TOWNER, P.H. 1995. Paradigm lost: mission to the cosmos in John and in David Bosch's biblical models of mission. Evangelical Quarterly, 67(2):99-119.

VAN DER MERWE, D.C.S. 1965. Verbond en sending. Potchefstroom : PU vir CHO. (Th.D. thesis.)

VAN RULER, A.A. 1945. Religie en politiek. Nijkerk : Callenbach.

VAN WOUDENBERG, R. 1992. Gelovend denken. Inleiding tot een christelijke filosofie. Kampen : Kok / Amsterdam : Buijten \& Schipperheijn.

VAN WOUDENBERG, R. 1996. Kennis en werkelijkheid. Tweede inleiding tot een christelijke filosofie. Kampen : Kok / Amsterdam : Buijten \& Schipperheijn.

VELDHUIZEN, P. 1995. God en mens onderweg. Hoofdmomenten uit de theologische geschiedbeschouwing van Klaas Schilder. Leiden : Groen. 
VERBOOM, W. 1996. Om het eeuwig welbehagen - over verbond en verkiezing. (In Van den Brink, G. red. Gegrond geloof. Kernpunten uit de geloofsleer. In bijbels, historisch en belijdend perspectief. Zoetermeer : Boekencentrum. p. 365-400.)

VICEDOM, G.F. 1965. The mission of God. Introduction to a theology of mission. Saint Louis : Concordia Publishing House.

WIELENGA, B. 1990. Volk van het land als missiologisch model: Oude Testament en zending in Zuidafrikaanse kontekst. Kampen : Mondiss.

WIELENGA, B. 1996. Over het Noachitische verbond als vredesverbond. Pactum salutis in vetere testamento. In die Skriflig, 30(4):457-470.

WIELENGA, B. 1998. Verbond en zending. Een verbondsmatige benadering van zending. Kampen : Mondiss.

WRIGHT, C.H.J. 1997. Living as the people of God. The relevance of Old Testament ethics. London : IVP. 